УПРОВАДЖЕННЯ ТЕХНОЛОГІЇ НАСТАВНИЦТВА

У ПРОЦЕС ПРОФЕСІЙНОГО РОЗВИТКУ

МАЙБУТНІХ ВИХОВАТЕЛІВ ЗАКЛАДІВ ДОШКІЛЬНОЇ ОСВІТИ

IMPLEMENTATION OF MENTORING TECHNOLOGY

IN THE PROCESS OF PROFESSIONAL DEVELOPMENT

OF FUTURE TEACHERS OF PRESCHOOL EDUCATION INSTITUTIONS

УДК 37.211 .24

DOI https://doi.org/10.32843/2663-

$6085 / 2020 / 25-1.32$

\section{Шаповалова О.В.,}

канд. пед. наук,

доцент кафредри дошкільної

і початкової освіти

Сумського державного педагогічного

університетуімені А.С. Макаренка

\section{Бутенко В.Г.,}

\section{канд. пед. наук,}

старший викладач

кафедри дошкільної і початкової освіти

Сумського державного педагогічного

університетуімені А.С. Макаренка

\section{Бойченко М.А.,}

докт. пед. наук,

доцент кафедри педагогіки

Сумського державного педагогічного

університетуімені А.С. Макаренка
У статті розглядається прочес упровадження технології наставництва у професійному розвитку майбутніх вихователів закладів дошкільної освіти. Виокремлено чотири послідовних етапи впровадження технології професійного розвитку майбутніх педагогів на основі наставництва в умовах закладу дошкільної освіти: аналітико-прогностичний, проблемно-пошуковий, операційно-технологічний, рефрлексивно-коригувальний. Реалізація означеної технології відбувається на декількох рівнях: адміністративному, командному (колегіальному), наставницькому та оперативному (особистісному).

На кожному з етапів реалізації ми виділили домінантні завдання діяльності, а саме: аналітико-прогностичний етап (формування мотивації профресійного розвитку у творчому освітньому середовищі), проблемно-пошуковий (розширення професійної компетентності молодих педагогів), операційно-технологічний (фрормування профресійно значущих якостей педагогів), ресрлексивно-коригувальний (розвиток рефрлексивної культури педагогів). Так, на аналітико-прогностичному етапі провідною умовою була розробка та реалізація щодо кожного молодого вихователя індивідуальної програми профресійного розвитку. На проблемно-пошуковому етапі - впровадження технології профресійного розвитку молодих вихователів на основі наставництва. На операційно-технологічному етапі - створення в колективі сприятливої психологічної атмоссрери творчої партнерської взаємодії. Охарактеризовано успішний профресійний розвиток майбутніх вихователів, який діагностується за такими критеріями: когнітивним, емоційно-ціннісним, компетентнісним. На підставі теоретичної розвідки визначили, що наставництво є однією з форм міжособистісної суб'єктної взаємодії у спільній діяльності, спрямованої на взаєморозвиток прикладних професійних компетенцій молодого вихователя та наставника. Поняття «профресійний розвиток» щодо молодого вихователя закладу дошкільної освіти подано як багатокомпонентну, інтегральну характеристику особистісно-профресійних змін, зумовлених системою зовнішніх та внутрішніх впливів у професійно-педагогічній діяльності.

Ключові слова:наставник, профресійний розвиток майбутніх вихователів, індиві- дуальна програма професійного розвитку, авторитетний вмотивований працівник, технологія наставництва.

The article reveals the process of implementing mentoring technology in the professional development of future teachers of preschool education institutions. Four successive stages of introduction of the technology of future teachers' professional development based on mentoring in the conditions of preschool education institution are allocated: analytical-prognostic, problem-search, operational-technological, reflexive-corrective. Implementation of this technology takes place at several levels: administrative, team (collegial), mentoring and operational (personal).

At each stage of implementation, we identified the dominant tasks, namely: analytical-prognostic stage (formation of motivation for professional development in a creative educational environment), problem-search (expansion of young teachers' professional competence), operational-technological (formation of teachers' professionally significant qualities), reflexivecorrective (development of teachers' reflexive culture). Thus, at the analytical-prognostic stage, the leading condition was development and implementation of an individual professional development program for each young teacher. At the problem-search stage - implementation of technology for young teachers' professional development on the basis of mentoring. At the operational-technological stage - creation of a favorable psychological atmosphere of creative partnership in the team. Successful professional development of future teachers is characterized, which is diagnosed by the following criteria: cognitive, emotional-value, competence.

Based on theoretical research, it has been determined that mentoring is one of the forms of interpersonal subjective interaction in joint activities aimed at mutual development of applied professional competencies of a young teacher and a mentor. The concept of "professional development" in relation to the young teacher of preschool education institution is presented as a multi-component, integral characteristic of personal and professional changes due to the system of external and internal influences in professional and pedagogical activities.

Key words: mentor, professional development of future preschool teachers, individual professional development program, authoritative motivated employee, mentoring technology.
Постановка проблеми в загальному вигляді. Сучасний розвиток суспільства вимагає змін системи профресійного вдосконалення педагогічних і науково-педагогічних працівників відповідно до умов соціально орієнтованої економіки та інтеграції України в європейське і світове освітнє співтовариство. Натомість невідповідність між викли- ками нашого часу та дійсним рівнем готовності педагогів до профресійної діяльності сьогодні надзвичайно гостро виявляється в усіх сфрерах освіти.

Як зазначено в Національній стратегії розвитку освіти в Україні на період до 2021 року, Законі України «Про освіту» (2017), Концепції реалізації державної політики у ссрері реформування загаль- 
ної середньої освіти «Нова українська школа» на період до 2029 року, реалії сьогодення вимагають від педагога високого рівня професіоналізму, творчої соціально-профресійної активності та здатності навчатись упродовж усього життя.

Аналіз останніх досліджень і публікацій. Найбільш активно проблема наставництва розвивалась у теорії педагогічної науки, й зарубіжної, й вітчизняної, починаючи з XIX століття (В. Мономах, Ж.-Ж. Руссо, Й. Песталоцці, Я. Коменський, К. Ставровецький), різні аспекти зазначеної проблеми досліджувались іу XX столітті (К. Ушинський, В. Сухомлинський, А. Макаренко, Н. Гаврилів).

Технологія наставництва активно вивчається зарубіжними науковцями, однак здебільшого в бізнесі. Проте і в освітній галузі визначено етапи становлення та розвитку наставництва, його переваги і недоліки (Б. Гершунський, М. Глікман, В. Загвязинський, Д. Джой-Меттьюз, Д. Меггінсон, М. Сюрте, Д. Дюбуа, І. Іванова, Д. Клаттербак, Н. Кузьміна, Р. Льюїс, А. Мамфрорд, Т. Назарова, Е. Парслоу, Е. Стокдейл, С. Тетерук, Л. Тілман та інші).

Виділення не вирішених раніше частин загальної проблеми. Практика засвідчує, що в умовах стрімких змін світу адаптуватись до нових умов професійної діяльності за максимально короткий час без сторонньої допомоги досить складно. Окреслене питання можна вирішити, цілеспрямовано керуючи професійним розвитком молодих фрахівців через надання повноважень наставнику щодо їх усебічної підтримки.

Метою статті $€$ впровадження технології наставництва у процес профресійного розвитку майбутніх вихователів закладів дошкільної освіти.

Виклад основного матеріалу. Успішність та результативність професійного розвитку майбутніх вихователів закладів дошкільної освіти залежить від системи управлінських впливів. На основі проведеного дослідження виведено таку дефініцію: «управління профресійним розвитком молодих вихователів» - це система спеціальних впливів, які спрямовані на забезпечення тісної взаємодії досвідчених та молодих спеціалістів у реальних умовах закладу дошкільної освіти 3 метою покращення результатів діяльності, за умови забезпечення профресійного розвитку учасників освітньої взаємодії.

Сутність системи управління профресійним розвитком молодих вихователів в умовах закладу дошкільної освіти полягає в упорядкуванні сукупності організаційно-педагогічних умов. Як умови успішного професійного розвитку майбутніх вихователів, ми визначили такі: розроблення й реалізація індивідуальної програми професійного розвитку молодого вихователя в умовах закладу дошкільної освіти; впровадження технології професійного розвитку молодих вихователів на основі наставництва; створення в колективі сприятливої психологічної атмоссрери творчої партнерської взаємодії.
На підставі аналізу низки трактувань сутності поняття «наставник» М. Зембицька виокремлює три його найважливіші характеристики:

1) наставник - це людина, яка має більший досвід або мудрість, ніж протеже;

2) наставник керує протеже, надає консультативну допомогу, спрямовану на його навчання та розвиток;

3) між наставником і протеже існує певний емоційний зв'язок, повага та довіра [4].

Ми погоджуємось із О. Самсоновою [9, с. 7] про те, що, беручи на себе обов'язки наставника, вихователь відкриває для себе низку переваг: відчуває потребу шукати нові перспективи у сфері своєї педагогічної діяльності; отримує задоволення від спілкування зі своїми підопічними; стимулює прагнення до самовдосконалення; наставництво сприяє розвитку власної педагогічної кар'єри, підвищенню його педагогічної кваліфікації, росту довіри до нього в педагогічному колективі; наставник отримує можливість не тільки ділитись власним досвідом із молодшими колегами, але також і вчитись у них, розширює свій арсенал навичок і вмінь, опановує сучасні технології навчання, стилі професійної діяльності тощо.

Отже, наставником може бути лише той, хто $€$ авторитетом. За Г. Коджаспаровою, авторитет педагога розуміємо як особливу профресійну позицію, котра визначає вплив на студентів і надає право приймати рішення, висловлювати оцінку, давати поради. Авторитет спирається на особистісні і професійні якості наставника: демократичний стиль співробітництва зі студентами, здатність до відкритого спілкування, позитивну Я-концепцію наставника, його прагнення до постійного вдосконалення, ерудованість, компетентність, справедливість і доброту, загальну культуру [5, с. 10].

$\mathrm{Ha}$ підставі вищезазначеного як робоче визначення пропонуємо таке: наставник - це досвідчений авторитетний умотивований працівник, консультант, координатор особистісногопрофесійного зростання молодих вихователів, який у межах освітнього простору навчального закладу здійснює їх педагогічний супровід, спрямований на взаємний професійний розвиток на засадах партнерства.

У процесі дослідження нами було з'ясовано, що фрорми наставництва майбутніх вихователів в умовах закладу дошкільної освіти класифікуються відповідно до таких характеристик: кількість учасників процесу: індивідуальне, групове, командне; вектора розвивальної дії: взаємне, колегіальне, зворотне; засобів наставництва: традиційне, електронне, інфрормаційне (книга та інші джерела); тривалості й інтенсивності програми наставництва: планове, ситуативне, корекційне; за способом впливу: пряме та опосередковане; за змістом: комплексне та предметно-тематичне; 
за особою, яка здійснює наставництво: досвідчений працівник закладу, визнаний авторитет у профресії [2]. Традиційною й найбільш поширеною формою педагогічного наставництва $€$ індивідуальне наставництво, в межах якого один наставник працює з одним молодим педагогом, які спільно становлять індивідуальний план наставництва 3 опорою на результати проведеної діагностики. Наставникрегулярно відвідуєуроки молодогопедагога, приділяючи особливу увагу їх попередньому й підсумковому аналізу, а також проводить власні майстер-класи з їх подальшим обговоренням [1].

Мусимо визнати, що найбільш корисним із позиції нашого дослідження (за способами організації) $€$ індивідуальне наставництво, яке сприяє професійному розвитку майбутнього вихователя, враховуючи індивідуальні особливості та наявні умови освітньоїустанови. Як ми вже зазначали, в сучасних умовах збільшується роль електронного наставництва, за умов зменшення кількості досвідчених вихователів в освітніх установах, але воно неспроможне забезпечити захист підопічного, посередництво між ним та адміністрацією закладу [8].

Вивченню особистісних рис наставника присвячене дослідження сучасного науковця Н. Гузій: усі риси особистості необхідно поділяти на загальні (свідомість), моральні (відображення соціальної характеристики особистості), інтелектуальні (розумові), вольові та емоційні (саморегуляція особистості). До моральних якостей зараховують гуманізм, працелюбство, чесність, принциповість, відповідальність тощо. До інтелектуальних - усвідомленість діяльності, логічність, розсудливість, об'єктивність та інше. До вольових якостей можна віднести самостійність, дисциплінованість, відповідальність, незалежність, активність тощо [3].

Деякі 3 дослідників звертають увагу на таку характеристику вихователя-наставника, як авторитет педагога. І. Кіндрат розуміє авторитет вихователя-наставника як особливу професійну позицію, яка визначає вплив на педагогів і надає право приймати рішення, висловлювати оцінку, давати поради. Авторитет спирається на особистісні і професійні якості наставника: демократичний стиль співробітництва, здатність до відкритого спілкування, позитивну Я-концепцію наставника, його прагнення до постійного вдосконалення, ерудованість, компетентність, справедливість і доброту, загальну культуру [6, с. 10].

Цінна позиція А. Фонарьова [10], який, досліджуючи психологічні характеристики профресіонала, виділяє чотири ієрархічно пов'язаних між собою рівні: індивідуально-виконавський, або інструментальний (задає діяльнісні та поведінкові якості, здатності практично діяти у професійному середовищі і проявляти себе), індивідуальнопсихологічний (виявляє групу індивідуально-психологічних властивостей та якостей особистості професіонала), соціально-психологічний (формує соціально-психологічні якості людини, в яких розкривається його місце й роль у спілкуванні та взаємодії 3 іншими людьми) й духовно-культурний (веде до визначення духовно-моральних якостей людини, в яких відбивається міра їі особистісної зрілості). Не принципово відмінна характеристика педагога-наставника, надана Л. Мороз [7].

Аналіз психолого-педагогічних джерел, наукової літератури, нормативних документів, власний багаторічний досвід управлінської діяльності та проведене дослідження дозволили констатувати, що в сучасній педагогічній практиці $€$ низка об'єктивних суперечностей, які зумовлюють необхідність моделювання, теоретичного обґрунтування технології професійного розвитку майбутніх вихователів в умовах ЗДО на основі наставництва. Для розробки технології було використано метод моделювання (К. Батароєв, В. Докучаєва, Т. Сорочан, В. Штофф), результатом якого стала технологічна модель як унаочнений образ системної роботи в ЗДО, спрямованої на професійний розвиток майбутніх вихователів на основі наставництва.

Виокремлено чотири послідовних етапи впровадження технології професійного розвитку майбутніх вихователів в умовах ЗДО на основі наставництва: аналітико-прогностичний, проблемно-пошуковий, операційно-технологічний, рефрлексивно-коригувальний.

Аналітико-прогностичний етап. Метою етапу $є$ діагностика професійного розвитку майбутніх вихователів та визначення їх проблем та утруднень. Виявлені індивідуально-психологічні характеристики майбутнього вихователя надають можливість утворити пари: молодий вихователь і наставник. Завдання цього етапу передбачають: вхідну діагностику рівня профресійного розвитку молодих вихователів; відповідно до індивідуально-типологічних особливостей молодих вихователів та наставників визначення та призначення вихователя-наставника; ознайомлення майбутнього вихователя 3 колективом та його традиціями; налагодження доброзичливих довірчих відносин між вихователем-наставником та молодим вихователем; залучення вихователем-наставників до навчальних тренінгів.

Проблемно-пошуковий етап. Метою етапу $€$ активна інтегративно-теоретична підготовча робота зі створення індивідуальної програми неперервного професійного розвитку майбутнім вихователем задля підвищення рівня професійно спрямованих знань та умінь і відомостей про безперервний профресійний розвиток, оволодіння проєктувальними знаннями й уміннями. Завданнями цього етапу є такі: розробка молодим вихователем спільно 3 наставником індивідуальної програми профресійного розвитку молодих вихователів; ознайомлення всіх ланок управління ЗДО з осно- 
вними напрямами індивідуальної програми розвитку молодих вихователів із визначенням участі та ступеня відповідальності кожного учасника процесу; демонстрація вихователем-наставником еталонного способу професійної педагогічної взаємодії 3 метою наслідування молодим вихователем; залучення молодих вихователів до перегляду відкритих форм роботи досвідчених вихователів ЗДО та пошук їх в інших інфрормаційних джерелах із метою аналізу та корекції переглянутих моментів; моніторинг поточних результатів професійного розвитку, профресійної діяльності молодих вихователів та коригування завдань програми.

Операційно-технологічний етап. Метою етапу $€$ набуття майбутніми вихователями професійної компетентності у процесі практичної педагогічної діяльності, під час якої вони творчо застосовують різні освітні технології, проявляють оригінальність, застосовують стандартні та нестандартні прийоми вирішення освітніх завдань. Завдання цього етапу охоплюють активний початок цілеспрямованого втілення індивідуальної програми професійного розвитку в життя; розвиток індивідуально-психологічних якостей, важливих для безперервного профресійного зростання і професійної педагогічної діяльності загалом через участь у розвивальних тренінгових програмах; вихователь-наставник активно залучається до аналітичної діяльності 3 метою пошуку оптимальних шляхів профресійного розвитку молодих вихователів.

Рефрлексивно-коригувальний етап. Метою його є здійснення поточного контролю за результатами професійного розвитку майбутніх вихователів, унесення коректив у застосування технології професійного розвитку молодих вихователів на основі наставництва. Завдання цього етапу охоплюють: вихідну діагностику рівня неперервного професійного розвитку молодого вихователя; напрацювання висновків щодо ефективності запропонованої технології та проведених науковометодичних заходів; коригування діяльності всіх залучених суб'єктів на всіх етапах роботи залежно від результатів діагностики.

Основним критерієм ефективності фрункціонування технології вважаємо позитивну динаміку рівнів професійного розвитку молодих вихователів: від критичного, стабілізаційного до нормативного й досконалого. Таким чином, упровадження технології наставництва дозволяє прогнозувати результат і здійснювати адекватні управлінські впливи в соціально-педагогічному середовищі; оцінювати ефективність технології управління професійним розвитком майбутніх вихователів на основі наставництва, здійснювати перспективне й поточне уточнення напряму професійного розвитку молодих педагогів в умовах Здо.

Висновки. Отже, процес реалізації технології професійного розвитку майбутніх педагогів на основі наставництва в умовах ЗДО складається із чотирьох етапів: аналітико-прогностичного, проблемно-пошукового, операційно-технологічного, рефрлексивно-коригувального, які співвідносяться з рівнями професійного розвитку молодих педагогів: від критичного, стабілізаційного до нормативного та досконалого.

\section{БІБЛІОГРАФІЧНИЙ СПИСОК:}

1. Безсонова О. Типологічний портрет молодого педагога ДН3. Педагогічні науки: збірник наукових праць Херсонського державного університету, (LXXXI(2)), Херсон. 2018. C. 98-102.

2. Безсонова О. Створюємо сприятливий соціально-психологічний мікроклімат у колективі: тренінг для вихователів. Вихователь-методист дошкільного закладу. № 12.2017. С. 16-21.

3. Гузій Н. Педагогічний професіоналізм: історико-методологічні та теоретичні аспекти. Монографрія. Київ: НПУ ім. М.П. Драгоманова. 2004. 243 с.

4. Зембицька М. Наставництво в системі середньої освіти США як психолого-педагогічна проблема. Науковий вісник Ужгородського національного університету: Серія «Педагогіка. Соціальна робота». Вип. 20. 2011. С. 41-44.

5. Коджаспирова, Г. Педагогика в схемах, таблицах и опорных конспектах. Москва : Айрис-Пресс. 2014. 345 c.

6. Кіндрат І. Управління освітнім процесом у дошкільному навчальному закладі на засадах інтеграції : автореф. дис. канд. пед. наук. Луганський національний університет ім. Тараса Шевченка, Луганськ. 2013. 200 с.

7. Мороз Л. Теоретичні та прикладні засади професійно-психологічного тренінгу працівників органів внутрішніх справ України : автореф. дис. доктора психол. наук. Київський національний університет внутрішніх справ, Київ. 2011. 35 с.

8. Осипова Т. Теоретико-методичні засади підготовки майбутніх учителів до педагогічного наставництва : автореф. дис. доктора пед. наук. Південноукраїнський національний педагогічний університет імені К.Д. Ушинського, Одеса. 2016. 43 с.

9. Самсонова О. Розвиток профресіоналізму вихователів дошкільних навчальних закладів у системі післядипломної освіти : автореф. дис. ... канд. пед. наук. Класичний приватний університет, Запоріжжя. 2016. 37c.

10. Фонарев А. Психология становления личности профрессионала. Воронеж: НПО «МОДЭК». 2005. 240 с. 